\title{
A Systemic Assessment of COVID-19 Impacts on Pacific Islands' Food Systems
}

\author{
Federico Davila ${ }^{1}$ \\ Institute for Sustainable Futures, University of Technology Sydney, \\ New South Wales, Australia \\ Steven Crimp \\ Climate Change Institute and Fenner School of Environment and Society, \\ The Australian National University \\ Bronwyn Wilkes \\ Fenner School of Environment and Society, \\ The Australian National University
}

\section{Abstract}

In this commentary, we present an analysis of how COVID-19 has impacted food systems in the Pacific Islands. The Pacific Islands region is home to over 10 million people across 22 countries, with hugely diverse agricultural and fisheries systems. The analysis is based on a systems framework developed by Allen and Prosperi (2016), which covers various aspects of human ecology food systems. We synthesized material from 21 interviews, news websites, emerging literature, and parallel published assessments of COVID-19 impacts in the region. We present examples of impacts across different elements of food systems throughout the region. We then apply a systems-based analysis to illustrate how the impacts of COVID-19 on Pacific food systems create an opportunity to find innovative ways of transforming localized and regional food, and create an opportunity to building resilience to future shocks.

Keywords: COVID-19, food systems, Pacific, shocks, systems thinking

\section{Introduction}

Over the six months between April 2020 and the time of writing, there has been a proliferation of reports and literature describing the projected impacts of COVID-19 on food systems. ${ }^{2}$ This literature describes the potential impacts of trade closures, loss of income, co-occurrence with extreme weather events, and political and structural

\footnotetext{
Corresponding author: federico.davila@uts.edu.au.

See, for example, special issues in the journals Agriculture and Human Values, and Food Security.
} 
inequalities (Altieri \& Nicholls, 2020; van der Ploeg, 2020), and proposes frameworks to assess the ongoing impacts of the pandemic (Béné, 2020; Savary et al., 2020). As scholars in human ecology, we are concerned with the ethical imperative of identifying ways in which these impacts can be mitigated, managed, or overcome, and which go some way to addressing the systemic structural issues that cause and perpetuate them. To do this, we must bring out perspectives from multiple actors across various domains that go beyond disciplinary silos and focus on the multiple dimensions of the crisis across various time horizons. As 2020 comes to an end, we need to reflect on the extent to which the projected impacts of this pandemic have come to pass and unforeseen impacts have emerged. In this commentary, we present evidence of how COVID-19 has impacted food systems in the Pacific Islands. We apply a systems framework developed by Allen and Prosperi (2016), which covers various aspects of the human ecology of food systems. Our analysis is based on synthesized material from key informant interviews, webinars, blogs, policy documents, and publications collected between May and September 2020 as part of the authors' various projects in Pacific food systems, as well as a project to assess COVID-19 impacts on food systems, commissioned by the Australian Centre for International Agricultural Research (ACIAR) (Robins et al., 2020). Our reporting of emerging evidence in Pacific Islands enables us to identify potential areas of focus for future research, policy, and business interventions to support the region.

\section{Pacific Islands' food systems and COVID-19 context}

Pacific Island countries comprise more than 2,000 islands and atolls in 22 countries and territories. While the region covers one-third of the Earth's surface, the total land area is only approximately $550,000 \mathrm{~km}^{2}$, representing 2 percent of the entire $30,000,000 \mathrm{~km}^{2}$ of the Pacific region (Barnett, 2011). This land area is home to 11 million people including Papua New Guinea (SPC, 2020b), and, excluding Papua New Guinea, 90 percent live within $5 \mathrm{~km}$ of the coast (Andrew et al., 2019) and a rapidly growing number live in and around major cities. While historically a more disperse population, urbanization is increasing in Pacific Island countries, and by 2050 over 50 percent of the Pacific population is expected to live in urban areas (UNESCAP, 2018). Demographically, over 50 percent of the population is under 50 years of age, and unemployment sits at 23 percent, much higher than global average of 12 percent (SPC, 2014).

Agriculture makes important contributions to national GDP and everyday livelihoods in the region, although the extent varies widely between areas, due to the different agroecological zones and variation in rainfall across the region (see Table 1). Despite the ongoing importance of agriculture, food production has declined in the region over the last few decades. In studying changes in agriculture, Farrell et al. (2020) 
found that between 1980 and 2016, crop production in the region (excluding Fiji and Papua New Guinea) declined from 1,200 to $800 \mathrm{~g} /$ capita/day. These declines are due to a mix of factors, including climate change, reductions in available arable land, increasing availability of cheap imported food, and diversification of livelihood strategies (Farrell et al., 2020; Plahe et al., 2013).

Table 1. Agriculture and fisheries context of Pacific Island countries.

\begin{tabular}{|c|c|c|c|c|c|c|c|c|}
\hline Indicator & Unit & Kiribati & Tuvalu & Samoa & Tonga & Fiji & $\begin{array}{l}\text { Solomon } \\
\text { Islands } \\
\end{array}$ & Vanuatu \\
\hline $\begin{array}{l}\text { Agricultural } \\
\text { land }\end{array}$ & $\begin{array}{l}\text { Percentage } \\
\text { of land } \\
\text { area }\end{array}$ & 42 & 60 & 12.4 & 45.8 & 23.26 & 3.9 & 15.3 \\
\hline $\begin{array}{l}\text { Agriculture } \\
\text { and fisheries, } \\
\text { value added }\end{array}$ & \begin{tabular}{|l} 
Percentage \\
of gross \\
domestic \\
product \\
(2018) \\
\end{tabular} & 30.8 & 16.5 & 9.8 & 17.2 & $\begin{array}{l}9.2 \\
(2012)\end{array}$ & 35 & 25.8 \\
\hline Top staples & $\begin{array}{l}\text { Ranked } \\
\text { most to } \\
\text { least, } \\
\text { based on } \\
\text { production } \\
\text { data }\end{array}$ & $\begin{array}{l}\text { coconut, } \\
\text { banana, } \\
\text { taro, } \\
\text { copra, } \\
\text { breadfruit }\end{array}$ & $\begin{array}{l}\text { coconut, } \\
\text { pulaka, } \\
\text { banana, } \\
\text { breadfruit, } \\
\text { taro, } \\
\text { cassava, } \\
\text { sweet } \\
\text { potato, } \\
\text { pawpaw } \\
\text { pumpkin }\end{array}$ & \begin{tabular}{|l|} 
taro, \\
chicken, \\
fish, \\
canned \\
mackerel, \\
rice, \\
banana, \\
brown \\
sugar, \\
coconut, \\
bread, \\
instant \\
noodles
\end{tabular} & $\begin{array}{l}\text { coconut, } \\
\text { cassava, } \\
\text { sweet } \\
\text { potato, } \\
\text { yam, } \\
\text { taro, } \\
\text { banana }\end{array}$ & $\begin{array}{l}\text { coconut, } \\
\text { taro, } \\
\text { cassava, } \\
\text { sweet } \\
\text { potato, } \\
\text { rice, } \\
\text { cereal, } \\
\text { banana, } \\
\text { yam, } \\
\text { maize }\end{array}$ & $\begin{array}{l}\text { rice, sweet } \\
\text { potato, } \\
\text { cassava, } \\
\text { yam, taro, } \\
\text { banana, } \\
\text { pumpkin, } \\
\text { vegetables, } \\
\text { coconut, } \\
\text { livestock }\end{array}$ & $\begin{array}{l}\text { taro, } \\
\text { yam, } \\
\text { cassava, } \\
\text { sweet } \\
\text { potato }\end{array}$ \\
\hline $\begin{array}{l}\text { UNDP } \\
\text { Human } \\
\text { development } \\
\text { index } \\
\text { ranking }\end{array}$ & Out of 189 & 132 & N/A & 111 & 105 & 98 & 153 & 141 \\
\hline
\end{tabular}

Source: Extracted from Robins et al. (2020, pp. 98-99).

Fisheries also contribute to the region's development. In simple terms, two major types of fishing are practiced:

- oceanic — with tuna being the region's primary catch, and

- coastal-which includes multiple fish species as well as cephalopods, crustaceans, shellfish, and eels.

Coastal fisheries, where fish are caught and consumed by families and surplus sold to markets, provide the primary or secondary source of income for up to 50 percent of households, and 50-90 percent of the animal-sourced protein consumed by households (SPC, 2015). The dependence on fisheries for household food security and incomes, as well as government revenue, is pronounced in Kiribati and Tuvalu, where 8-10 percent of their gross domestic product is obtained from fisheries (Gillett, 2016). 
With a surge of trade liberalization in the mid-1990s, the region experienced a rapid increase of cheap imported processed foods such as noodles, rice, and wheat (Charlton et al., 2016; Plahe et al., 2013). This has altered food environments and, coupled with increasingly sedentary lifestyles, has contributed to the growing burden of noncommunicable diseases in the region, including stunting, micronutrient deficiencies, obesity, and diabetes. It is possible to simultaneously suffer from micronutrient deficiency and obesity, which can result when an abundance of calories is available in the form of energy-dense, nutrient-poor food, such as highly processed foods. In several Pacific Islands countries, rates of obesity, diabetes, kidney disease, and nutritional deficiencies are above the global average (Global Nutrition Report, 2020; IHME, 2018). ${ }^{3}$ The Pacific is also highly exposed to climate change, as it contains some of the most vulnerable countries in the world to sea level rise and increasing extreme weather events.

COVID-19 in the Pacific has been experienced differently from other parts of the world, as despite having isolated cases, the region is largely COVID-19 free as of September 2020. At the time of research (June-August), seven out of 22 Pacific countries had under 700 infections and 8 deaths. ${ }^{4}$ Rapid action by governments to fully close borders managed to control outbreaks-a vital response, given the fragility of health systems in the region. However, despite the relatively low numbers of COVID-19 infections, the socioeconomic impacts of the pandemic have been severe, undermining existing food and nutritional security, and also negatively impacting livelihoods across the region. In this unfolding scenario, urban poor, rural women, and landless farmers have been disproportionately affected. In response, many nations in the region have reprioritized the importance of food activities as a core contributor to sustainable development.

For our rapid systems analysis, we synthesized material from 21 key informant interviews (including 7 women), which lasted between 30 and 60 minutes. Targeted sampling was undertaken across seven countries and conducted in June 2020, along with review of news websites, emerging literature, and parallel published assessments of COVID-19 impacts in the region (ADB, 2020; WFP, 2020). Our analysis focused on seven countries representing three categories of islands. The first category comprised of the larger Melanesian countries of Fiji, Solomon Islands, and Vanuatu. The second category comprised of the Polynesian countries of Samoa and Tonga. The third category comprised of the coral-based atoll islands of Tuvalu and Kiribati. We excluded United States, United Kingdom, and French territories; Papua New

3 We compared the prevalence of nutritional deficiencies, diabetes, and kidney disease in the following countries with that of the global average: Tonga, Samoa, Fiji, Vanuatu, Solomon Islands, and Kiribati. We used data for both sexes and all ages.

4 At the time of writing, in October 2020, the situation is more severe: over 10,000 cases and 95 deaths. Most countries remain COVID-19 free, with large clusters in Guam and French Polynesia. 
Guinea was not included in our rapid analysis given its enormous agroecological diversity, substantially larger population, and the fact that a parallel assessment was conducted in that country.

In the section that follows, we first present a series of impacts across different food system components. We then analyze the material through a causal loop diagram and the broad application of a human ecology perspective to show opportunities for interventions to support Pacific Island food system recovery from COVID-19 shocks.

\section{Impacts on food and nutrition security}

Various forms of national lockdowns and movement restrictions were implemented by the seven countries between March and July 2020. These movement restrictions resulted in impacts on the normal operation of distribution networks of local food supply, and people's ability to access food. The nature of lockdowns meant farmers and distributors were confined to their home provinces, limiting the distribution of food to larger markets in cities. Similar to other recent analyses, we found that particular social groups were exposed to greater food insecurities from COVID-19 than others. Most sensitive were the urban poor, landless farmers, and rural women (CARE, 2020; PIFON, 2020).

The economic impacts of the pandemic have been many and varied, but most significant are the collapse in tourism and the reduction in remittances from family members working outside of the Pacific. The near total collapse of Pacific tourism has meant unemployment has risen dramatically. Estimates established in April for scenarios where travel bans extend for more than seven months were for US\$1.9 billion in lost revenue across the Pacific (SPC, 2020a). Given travel bans now are set to extend beyond this timeframe, economic losses will be even higher. Fiji is particularly vulnerable, with tourism contributing to 40 percent of GDP, employing over 150,000 people, and facing projected losses of up to US\$600 million. According to a recent analysis (SPC, 2020a), the contributions of remittances to GDP in 2018 was 40.7 percent in Tonga and 16.4 percent in Samoa. Remittances are important for cushioning economic shocks and play a critical role in household income, given the limited capacity of many Pacific governments to provide cash-based social protection (Edwards, 2020). In Fiji, income from remittances is expected to have reduced by 15 percent for the period April to September 2020 (McClure, 2020), eroding important social protection functions.

Women in the Pacific are potentially more exposed to extreme food system shocks, given their often under-recognized role in the economy (FAO, 2020). The majority of market food vendors operating in the Pacific are women-acting as middle agents between producers and consumers, on top of their traditional roles in household food procurement and preparation (UN Women, 2016). A recent study 
by Clissold et al. (2020) found that after extreme cyclones, women play a crucial role in recovering economies and supporting social networks given their role in various parts of value chains. In our study, multiple interviewees noted women in Fiji self-organizing to arrange transport of produce between regions and ensuring incomes continued to flow despite movement restrictions. Our interviews also highlighted that with unemployed urban people moving back to rural households, local women have been exposed to increased household demands and are potentially eating less to accommodate larger households. Recovery strategies seeking to liberate the entrepreneurial skills of women must also address the multiple additional roles they perform in post-crisis response, such that women do not shoulder a disproportionate share of the burdens of recovery and resilience building.

\section{Impacts on ecosystems}

During the early days of the pandemic, a surge in demand for localizing food production and increased fresh vegetable production was experienced by many rural communities. Between April and July 2020, increased pressure on rural areas from urban-rural migration was exacerbated. In Tuvalu, the only rural village in the island of Funafuti received new arrivals of people from the capital on a daily basis. Most of the arrivals came in using a new road-nicknamed the "COVID-19 Road"—which was created to enable transport and new housing. These movements of people have led to widespread clearing of land for food production. Recent analysis from Malaita and the Russell Islands in Solomon Islands found rural populations have increased by as much as 7.1 percent (Eriksson et al., 2020; Wale \& LMMA Network, 2020). Local fishers in Yandina, Russell Islands, estimated 25-50 percent more fish being caught to service the demands of this growing population, which has resulted in contraventions of existing marine regulations related to size limits for clams, crayfish, trochus, and coconut crabs (Wale \& LMMA Network, 2020). It is unclear what the specific longterm impacts of increased pressures in rural areas will be on ecosystems, beyond the immediate observations of increased fishing practices or land clearing, which are likely to have implications for biodiversity, soil health, and erosion, among other things.

In April 2020, as the region enforced COVID-19 restrictions, the Category 5 Tropical Cyclone (TC) Harold impacted Fiji, Solomon Islands, Vanuatu, and Tonga. Some communities in northern Vanuatu have experienced serious food scarcity resulting from the strong winds and localized flooding. The effect of the cyclone combined with COVID-19 control measures to further impact food production in some provinces. The effects of TC Harold in Vanuatu were severe, with 95 percent of homes destroyed on the island of Pentecost, where crop damage ranged from 50 percent to 100 percent, and 27 percent of the population were estimated to have been displaced (Ober \& Bakumenko, 2020). With the loss of home gardens and crops, increases in fishing were identified, with 15 out of 23 sites recording an increase in fishing pressure on reefs or near community shore lines (Steenbergen et al., 2020). 


\section{Impacts from changing policies and institutions}

As a response to the economic impacts described above, public institutions have focused on agricultural incentives, subsidies, and stimulus packages to support existing and new forms of agriculture. Home gardening has been promoted throughout the region as a way of securing immediate vegetable supplies for those able to grow their own food. Common barriers to establishing home gardens, including access to planting material, seeds, and composting, have been partially addressed through various stimulus packages, using agriculture as a social protection measure to generate economic activities. In Fiji, the government's stimulus package distributed 11,602 seedling packages to citizens, focusing on corporate employees who became unemployed due to the COVID-19 crisis. In Solomon Islands, government and farmer organizations have enhanced seed distribution and access via a stimulus package offered to larger-scale agricultural and fisheries operators. Despite these production limitations in peri-urban areas, a recent analysis (PIFON, 2020) found that there has been a surplus in labor, overall food outputs have remained stable, and the drop in demand from international markets and tourists has now created surplus of some foods in domestic markets.

Price fluctuations have varied throughout the region, depending on the supply and availability of food. Reports from Fiji indicate that the price for a whole fish had declined from FJ\$45 to FJ\$25. The price of pineapples was also down from FJ \$5 for a heap to FJ $\$ 2.50 .^{5}$ Part of the reason for reduced prices has been the surplus of commodities in markets resulting from suppressed hotel demand and more fishing. While this has left more produce available to locals, the types of produce grown for tourists are not always the same as those desired by locals for culturally appropriate nutrition and food security. Complementing our findings on price fluctuations, a study in the Solomon Islands found a doubling in price of commodities outside Honiara. In Malaita, 48 percent of respondents noticed higher prices for rice and 46 percent noticed higher prices for canned tuna (Eriksson et al., 2020). There have been some government responses to manage food prices. For example, in Vanuatu the COVID-19 Food Security Response Plan supported commercial food baskets, where produce from farmers was packaged for urban citizens at affordable prices.

Reduced income has meant some people have had to find new ways of making money-for example, in Tonga there have been reports of new food outlets and informal stalls opening as new businesses in main towns. The lockdowns have also reignited interest in informal bartering systems for e-commerce. In Fiji, the Barter

5 A heap of fruit or single fish is common unit of measurement in Pacific Islands' local markets. 
for Better Fiji group established in April 2020 now has over 180,000 members. While not food-specific, the group has enabled non-cash-based product exchanges during the lockdowns.

\section{Human ecology systems analysis}

The brief examples above show how COVID-19 has impacted different aspects of food systems, ranging from production to consumption activities. The context of Pacific Island food systems, where agriculture and fisheries continue to play crucial role for everyday livelihoods, meant that institutions and policies had to rapidly support these sectors. Our findings indicate that governments and communities have been swift in adapting to lockdown measures, and narratives of home gardening and focusing on domestic food production to buffer further shocks have gained momentum. However, the long-term economic impacts from the loss of tourism, remittances, and international food markets means that there are long-term risks to livelihoods, and potentially to ecosystems as increased pressure on land and marine systems increases.

To synthesize the various impacts above in the context of a human ecology system, we drew from an existing analytical framework developed by Allen and Prosperi (2016). Their framework helps identify feedbacks between food system levels of exposure, sensitivity, impacts, recovery, and overall resilience to a particular disturbance. We organized the emerging material from our study into these categories to help understand how COVID-19 was impacting different aspects of the food system. Using causal loops as a tool for capturing linkages between system variables (Proust \& Newell, 2017), we developed Figure 1 as a representation of key feedback structures and to identify intervention points that would promote both short-term recovery as well as long-term resilience of food systems in the region.

Agriculture, fishing, and rural livelihoods are seen in Figure 1 as core components of recovery for the region, and which can also contribute to culturally appropriate food security and nutrition outcomes, and potentially contribute to reducing the burden of noncommunicable disease in the region. The increased interest in home gardening and a focus on agriculture as an economic recovery strategy can provide immediate opportunities for increasing the supply of essential fresh foods in the region and support culturally embedded healthy eating practices. However, it remains unclear if there will be sufficient adoption of these agricultural practices in the long term, especially for those new to farming and working on previously "idle" land. If the emerging COVID-19 recovery paradigm is one that focuses more on supporting local food systems, this needs to be done in a way that also supports building resilience to extreme climate shocks and sudden food shortages. Efforts to enhance production will need to be embedded in ecological- and climate-sensitive methods, and coupled with innovative business models to support the particular logistics and distribution needs of the region. 


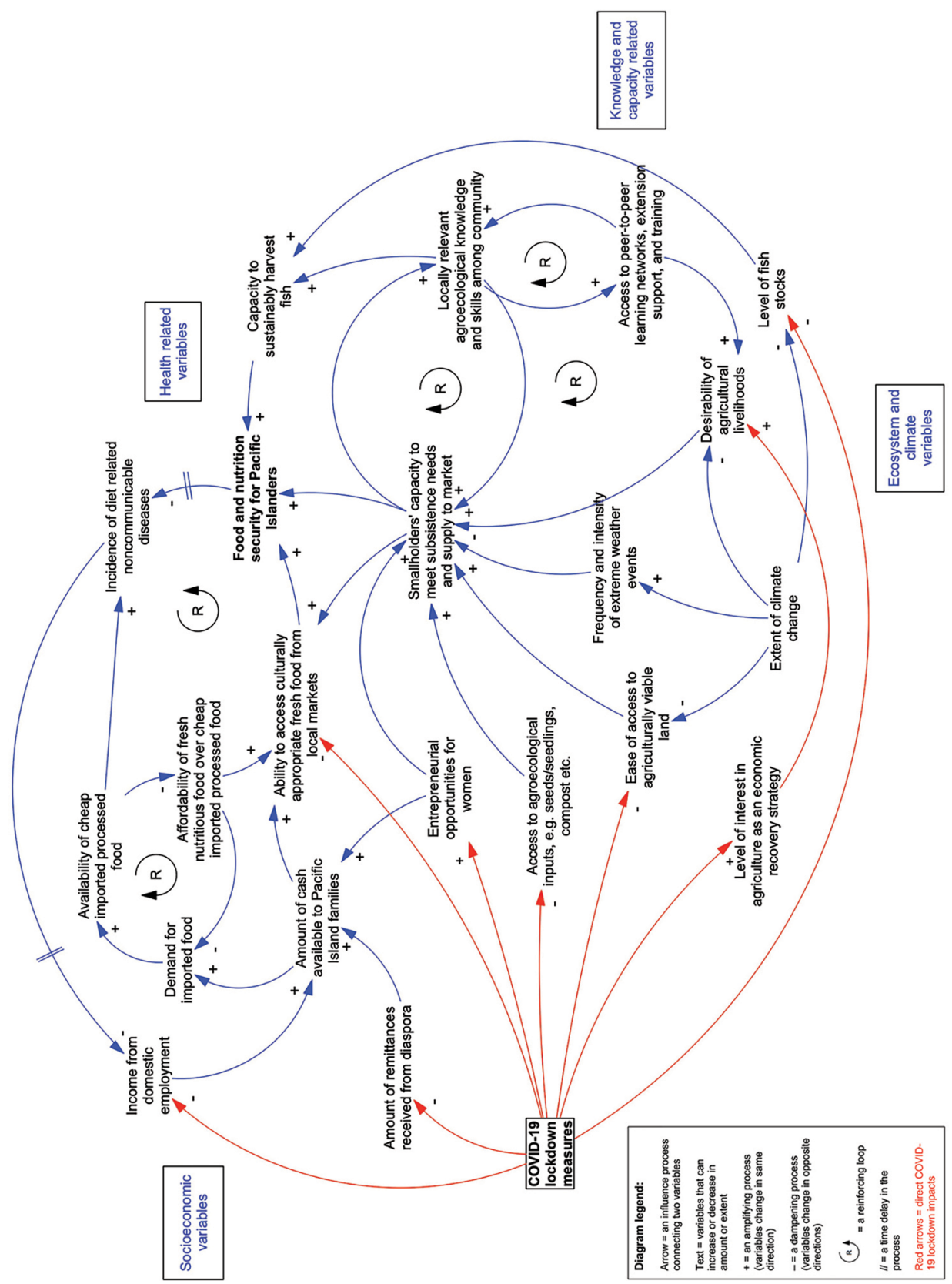

Figure 1. Feedbacks between major food system variables, COVID-19 impacts, and immediate responses.

$\mathrm{R}=\mathrm{a}$ reinforcing loop.

Source: Authors' representation. 
Efforts to enhance and achieve nutrition security create opportunities to support new ways of farming that focus on sustainable practices and include women and youth. This could create greater long-term diversity of farming communities, and hence greater food system resilience. Codesigning such strategies with local women will be important to achieve socially desirable outcomes that avoid women bearing a disproportionate burden of efforts to achieve resilient food and nutrition security.

To ensure the long-term future of food systems in the region, agricultural recovery strategies will also have to ensure equitable economic development. COVID-19 recovery provides an opportunity to redress underlying inequalities and use agriculture as an inclusive economic recovery strategy. This can go some way towards creating spaces for greater food sovereignty, where communities and governments determine their own food production systems that support social inclusion and the sustainable production of culturally appropriate nourishing food. Agriculture and fishing activities can also form part of important social protection and stimulus activities that promote better management of natural resources, livelihoods, and nutritional security.

While COVID-19 continues to have multiple impacts on Pacific food systems, it also provides an opportunity to reshape how we frame our research and practice. As we continue to learn and understand how food systems have responded to COVID-19 and other disruptions, systems thinking tools and a human ecological perspective can support the identification and development of interventions that simultaneously assist with recovery and address existing health problems and structural inequalities, while building resilience to future food system risks.

\section{Acknowledgements}

This study was supported by the Australian Centre for International Agricultural Research, contract CS/2020/146. We thank all the people involved in continuing to support food security and recovery during COVID-19, and the time and different types of input provided by participants.

\section{References}

ADB. (2020). Food security in Asia and the Pacific amid the COVID-19 pandemic. Asian Development Bank. doi.org/10.22617/brf200176-2

Allen, T., \& Prosperi, P. (2016). Modeling sustainable food systems. Environmental Management, 57(5), 956-975. doi.org/10.1007/s00267-016-0664-8 
Altieri, M. A., \& Nicholls, C. I. (2020). Agroecology and the reconstruction of a postCOVID-19 agriculture. The Journal of Peasant Studies, 47(5), 881-898. doi.org/10.1080/ 03066150.2020 .1782891

Andrew, N. L., Bright, P., de la Rua, L., Teoh, S. J., \& Vickers, M. (2019). Coastal proximity of populations in 22 Pacific Island countries and territories. PLOS ONE, 14(9), e0223249. doi.org/10.1371/journal.pone.0223249

Barnett, J. (2011). Dangerous climate change in the Pacific Islands: Food production and food security. Regional Environmental Change, 11(1), 229-237. doi.org/10.1007/ s10113-010-0160-2

Béné, C. (2020). Resilience of local food systems and links to food security-A review of some important concepts in the context of COVID-19 and other shocks. Food Security, 12, 805-822. doi.org/10.1007/s12571-020-01076-1

CARE. (2020). Rapid gender analysis of COVID-19 Pacific region [Version 1, March 26]. CARE International. www.care.org.au/rapid-gender-analysis-covid-19/

Charlton, K. E., Russell, J., Gorman, E., Hanich, Q., Delisle, A., Campbell, B., \& Bell, J. (2016). Fish, food security and health in Pacific Island countries and territories: A systematic literature review. BMC Public Health, 16, 285. doi.org/10.1186/s12889-016-2953-9

Clissold, R., Westoby, R., \& McNamara, K. E. (2020). Women as recovery enablers in the face of disasters in Vanuatu. Geoforum, 113, 101-110. doi.org/10.1016/j.geoforum.2020. 05.003

Edwards, R. (2020). Bubble in, bubble out: Lessons for the COVID-19 recovery and future crises from the Pacific. World Development, 135, 105072. doi.org/10.1016/j.worlddev. 2020.105072

Eriksson, H., Ride, A., Boso, D., Sukulu, M., Batalofo, M., Siota, F., \& Gomese, C. (2020). Changes and adaptations in village food systems in Solomon Islands: A rapid appraisal during the early stages of the COVID-19 pandemic. WorldFish. hdl.handle.net/20.500. $12348 / 4195$

FAO. (2020). Gendered impacts of COVID-19 and equitable policy responses in agriculture, food security and nutrition [Policy brief]. Food and Agriculture Organization. www.fao. org/policy-support/tools-and-publications/resources-details/en/c/1276740/

Farrell, P., Thow, A. M., Wate, J. T., Nonga, N., Vatucawaqa, P., Brewer, T., ... Andrew, N. L. (2020). COVID-19 and Pacific food system resilience: Opportunities to build a robust response. Food Security, 12, 789-791. doi.org/10.1007/s12571-020-01087-y

Gillett, R. (2016). Fisheries in the economies of Pacific Island countries and territories. The Pacific Community (SPC). www.spc.int/sites/default/files/resources/2018-05/ Gillett_16_Benefish.pdf

Global Nutrition Report. (2020). Country nutrition profiles [Data set]. Retrieved July 10 and November 6, 2020, from globalnutritionreport.org/resources/nutrition-profiles/ 
IHME. (2018). Global burden of disease compare [2017 Data set]. Institute for Health Metrics and Evaluation. Retrieved July 12, 2020, from vizhub.healthdata.org/gbd-compare

McClure, H. (2020, July 22). COVID-19-The Pacific response: 22 July. Asia \& The Pacific Policy Society. www.policyforum.net/covid-19-the-pacific-response-22-july/

Ober, K., \& Bakumenko, S. (2020). A new vulnerability: COVID-19 and Tropical Cyclone Harold create the perfect storm in the Pacific [Issue brief]. Refugees International. www. refugeesinternational.org/reports/2020/6/1/a-new-vulnerability-covid-19-and-tropicalcyclone-harold-create-the-perfect-storm-in-the-pacific

PIFON. (2020). COVID-19 Overview: Expected impacts in the Pacific. Pacific Island Farmer Organizations. pacificfarmers.com/resource/covid-19-overview-expected-impacts-in-thepacificl

Plahe, J. K., Hawkes, S., \& Ponnamperuma, S. (2013). The corporate food regime and food sovereignty in the Pacific Islands. The Contemporary Pacific, 25(2), 309-338. doi.org/ 10.1353/cp.2013.0034

Proust, K., \& Newell, B. (2020). Constructing influence diagrams and causal loop diagrams [Student guide]. Fenner School of Environment \& Society, The Australian National University. hdl.handle.net/1885/201846

Robins, L., Crimp, S., van Wensveen, M., Alders, R. G., Bourke, R. M., Butler, J., ... Webb, M. (2020). COVID-19 and food systems in the Indo-Pacific: An assessment of vulnerabilities, impacts and opportunities for action (ACIAR Technical Report TR096). Australian Centre for International Agricultural Research. aciar.gov.au/publication/covid-19-and-foodsystems

Savary, S., Akter, S., Almekinders, C., Harris, J., Korsten, L., Rötter, R., ... Watson, D. (2020). Mapping disruption and resilience mechanisms in food systems. Food Security, 12, 695-717. doi.org/10.1007/s12571-020-01093-0

SPC. (2014). The Pacific Youth Development Framework 2014-2023. Secretariat of the Pacific Community. www.spc.int/sites/default/files/resources/2018-05/Pacific_Youth_ Development_Framework.pdf

SPC. (2015). A new song for coastal fisheries-pathways to change: The Noumea strategy. The Pacific Community (SPC). coastfish.spc.int/component/content/article/461-a-newsong-for-coastal-fisheries.html

SPC. (2020a). Economic and social vulnerability indicators in Pacific Island countries and territories [Data set]. Statistics and Development Division (SDD), The Pacific Community (SPC). Retrieved June 5, 2020, from sdd.spc.int/disasters-data/covid-19

SPC. (2020b). Pacific Island populations 2020. Statistics for Development Division, the Pacific Community (SPC). sdd.spc.int/digital_library/pacific-islands-2020-populations-poster 
Steenbergen, D. J., Neihapi, P. T., Koran, D., Sami, A., Malverus, V., Ephraim, R., \& Andrew, N. (2020). COVID-19 restrictions amidst cyclones and volcanoes: A rapid assessment of early impacts on livelihoods and food security in coastal communities in Vanuatu. Marine Policy, 121, Article 104199. doi.org/10.1016/j.marpol.2020.104199

UN Women. (2016). Markets for change Vanuatu. asiapacific.unwomen.org/en/digital-library/ publications/2016/02/markets-for-change-vanuatu

UNESCAP. (2018). Ocean cities of the Pacific Islands: Policy brief \#1 The ocean and the city. United Nations Economic and Social Commission for Asia and the Pacific. www.unescap. org/resources/ocean-cities-policy-brief-1-ocean-and-city

van der Ploeg, J. D. (2020). From biomedical to politico-economic crisis: The food system in times of Covid-19. The Journal of Peasant Studies, 47(5), 944-972. doi.org/10.1080/ 03066150.2020 .1794843

Wale, J., \& LMMA Network. (2020). COVID-19 impacts on fishing and coastal communitiesUpdate \#2: Russell Islands, Solomon Islands. Locally-Managed Marine Area Network. lmmanetwork.org/wp-content/uploads/2020/08/LMMA-Network-and-Wale.-CovidUpdate-2-Russell-Islands.-30.05.2020.pdf

WFP. (2020). Macro analysis of COVID-19-threats to food security and livelihoods in Asia and the Pacific. World Food Programme. www.wfp.org/publications/macro-analysiscovid-19-threats-food-security-and-livelihoods-asia-and-pacific 
This text is taken from Human Ecology Review, Volume 26, Number 1, 2020, published by ANU Press, The Australian National University, Canberra, Australia. doi.org/10.22459/HER.26.01.2020.02 